\title{
THE REWARDS OF ENTREPRENEURSHIP: EXPLORING THE INCOMES, WEALTH AND ECONOMIC WELL-BEING OF ENTREPRENEURIAL HOUSEHOLDS
}

\author{
Sara Carter \\ Professor of Entrepreneurship and Head of Department, Hunter Centre for \\ Entrepreneurship, University of Strathclyde Business School \\ Visiting Professor, Nordland Research Institute, Bodo, Norway \\ Mail Address: \\ Hunter Centre for Entrepreneurship, University of Strathclyde, Livingstone Tower, \\ Richmond Street, Glasgow, Scotland, G1 1XH, \\ Tel: + 441415483276 \\ Email: sara.carter@strath.ac.uk
}




\title{
THE REWARDS OF ENTREPRENEURSHIP: EXPLORING THE INCOMES, WEALTH AND ECONOMIC WELL-BEING OF ENTREPRENEURIAL HOUSEHOLDS
}

\begin{abstract}
The financial rewards and consequences of entrepreneurship for the individual are unknown. Prior studies have focused on self-employment income estimates, and have highlighted the low median earnings that may be anticipated. The apparent financial irrationality of entrepreneurship is typically explained in terms of non-pecuniary compensating factors, such as autonomy and satisfaction. However, the financial rewards of entrepreneurship are multi-faceted and include different types and amounts of rewards at different stages of the business life-cycle. More accurate reflections of entrepreneurial rewards require researchers to move away from the use of narrow and static measures, and instead focus on a broad set of indicators that collectively contribute to overall economic wellbeing. Entrepreneurial rewards are not only determined by business rationality, but are influenced by household needs that evolve over time. Hence, the analysis of entrepreneurial rewards requires an approach that captures the processes of reward decision-making over the business lifecycle, while contextualising reward decisions within the entrepreneurial household.
\end{abstract}

\section{Introduction}

Recent studies have highlighted the dramatic and sustained loss of income an individual may anticipate moving from employment into entrepreneurship (Hamilton, 2000; Blanchflower, 2004; Blanchflower and Shadforth, 2007; Shane, 2008). Median incomes from entrepreneurship are lower than equivalent incomes from employment, and the earnings difference increases over time (Hamilton, 2000). These studies highlight the apparently precarious nature of entrepreneurship, where individual risks are rewarded by volatile, often meagre returns. But contradictory evidence also exists. A different body of work has shown entrepreneurs to be significantly wealthier than people who work in paid employment, with disproportionately high levels of household assets and total net worth (Quadrini, 2000; Cagetti and De Nardi, 2006; 
Nanda, 2008). In contrast to studies of incomes, studies of wealth reinforce the popular view that entrepreneurs enjoy living standards far in excess of those typically observed among the majority of employees.

Such contrasting claims encourage a closer examination of the precise scale and nature of the financial rewards that may be derived from entrepreneurship. While labour economists have engaged with these issues with some enthusiasm, few entrepreneurship scholars have focused on the individual financial rewards and consequences of venture creation. This apparent lack of interest is, in itself, worthy of consideration. Clearly, studying the financial rewards of entrepreneurship is rife with methodological concerns; studying earnings is complex, inconvenient, and raises immediate questions regarding both the unit of analysis used and the difficulty of data collection (Davidsson and Wiklund, 2001; Chandler and Lyon, 2001). Nevertheless, it is also possible that entrepreneurship scholars have been prey to a set of popular assumptions about entrepreneurial incomes that are untested, inconsistent, and ideological. Popular assumptions include views such as: successful entrepreneurship leads to fabulous wealth, failure leads to financial catastrophe; entrepreneurial incomes are low, but the capital gain is great; low entrepreneurial incomes are compensated by non-pecuniary benefits; and, it does not matter what entrepreneurs earn, because 'real' entrepreneurs will be entrepreneurial no matter what the rewards. Such stereotypical views have persisted largely because so little is understood about the financial consequences and rewards of entrepreneurship.

The purpose of this paper is to consider how prior research has approached entrepreneurial rewards and secondly to propose new directions for future research 
that focus on entrepreneurial reward structures and decision processes, using multidimensional measures of economic well-being, contextualized within the entrepreneurial household. The paper starts by reviewing the various ways in which the financial returns to entrepreneurship have been theorised and measured. The conflicting evidence of prior studies highlights the complexities involved in studying entrepreneurial rewards. The financial rewards of entrepreneurship are multi-faceted, and include different types and amounts of rewards at different stages of the business lifecycle. The close, often inseparable, relationship between the entrepreneur and the firm suggests that decisions about the individual's financial rewards are rarely clearcut; rather, they are often ad hoc, short term and reversible. However, previous studies have relied on narrow and static measures of income or wealth, which ignore the range of financial rewards available to the entrepreneur and fail to capture the ways in which economic wellbeing is constructed over the course of the business venture. The paper discusses the components of economic well-being within an entrepreneurial setting, before considering the context of entrepreneurial reward decisions. Reward decisions are not only determined by business rationality, but are influenced by family and household needs (Ram, 2001; Aldrich and Cliff, 2003). Hence, the analysis of entrepreneurial rewards requires an approach that captures the structures, processes and dynamics of reward decision-making over the business lifecycle, while contextualising decisions within the entrepreneurial household (Wheelock and Baines, 1998; Zahra, 2007). The paper concludes by discussing the implications for future research. 


\section{Theorising Entrepreneurial Earnings}

A range of theories have focused on the precise sources of value created by entrepreneurial production and exchange activities. Returns to entrepreneurship are usually conceived as entrepreneurial rents. These are typically characterized as being temporary and, though this is subject to some debate, ex ante non-contractible. Entrepreneurial rents have been variously conceived as a return to uncertainty bearing (Cantillon, 1964; Von Thunen, 1960), managerial judgment (Knight, 1942; Casson, 1995), innovation and intuition (Schumpeter, 1934, 1991), alertness (Kirzner, 1979), market making, and leadership (Casson, 2005). In the resource-based view of the firm, rents are not attributed to any specific resource, but "represent the value created by the entrepreneur's unique (heterogeneous) combination of assets" (Ross and Westgren, 2006: 409). Theories explaining the derivation of entrepreneurial rents typically emphasise the different types of payments that entrepreneurs can gain, but rarely attempt to allocate a monetary value to entrepreneurial activities. Types of payment include the difference between uncertain selling price and certain buying price (Cantillon, 1964), management salary or Ricardian gain (Schumpeter, 1934), and risk-adjusted Ricardian gain less the costs of supervision and capital (Casson, 2005).

The various perspectives also differ in considering entrepreneurship as a function of the individual, as often portrayed in classical schools, or in seeing the individual as interior to the firm (Casson, 1995; Foss and Klein, 2004). This issue is a key concern in the consideration of entrepreneurial earnings. A focus on the individual draws attention to the cash payments received, for example, in the form of drawings, salary and dividends, but neglects the long term accretion of wealth and assets nominally 
owned by the firm. A focus on the firm includes profits and capital gain over time, but obscures the living standards, in the form of relative earnings and consumption, of the individual entrepreneur.

Labour economists view the rewards of entrepreneurship through the lens of the individual. Assuming individuals to be wealth maximizers, various theories attempt to predict and explain incomes derived from entrepreneurship. Matching and learning models (Jovanovic, 1982; Carruth, Collier and Dickerson, 2004) suggest that individuals have often unobserved, sector specific skills and select sectors that offer relative advantage. Where individuals are uncertain of their best placement, they learn through experience the sector which best matches and rewards their abilities. The assumption that individuals move out of sectors where they are unable to maximise their rewards, implies that self-employed earnings should, over time, exceed those of employees, as low ability entrepreneurs migrate back into employment (Rees and Shah, 1986; Evans and Leighton, 1989). Human capital investment models also typically predict entrepreneurial earnings to be higher (Lazear, 2005). Not only are the individual's investments not shared with an employer, the substantial human capital input into entrepreneurship limits the effects of individual risk (Polkovnichenko, 2002). An alternative view of human capital investment theory predicts the opposite (Astebro and Thompson, 2007). Rather than entrepreneurs with generalist skills having higher incomes, Astebro and Thompson (2007) predict lower incomes for entrepreneurs accruing from their more varied skills and work experience. 


\section{Measuring Entrepreneurial Earnings}

Despite theoretical interest in the returns to entrepreneurship, there has been little supporting empiricism. Most studies of earnings exclude entrepreneurs and little is known of the role of personal remuneration in the business start-up decision or the determinants of earnings once trading (Parker, 1997; Hamilton, 2000). The omission of entrepreneurs is attributable partly because of their ambiguous legal status and partly because of the complexity involved in measuring and interpreting their earnings.

The large datasets typically used in measuring earnings, e.g. the US Panel Survey on Income Dynamics, Survey of Income and Program Participation, and the UK Labour Force Survey, classify individuals by occupation. These occupational categories do not include entrepreneurship, but do include self-employment and business ownership. Clearly, the self-employed are not necessarily entrepreneurs or even business owners, and business owners are not always self-employed, being legally employed by their company. Nevertheless, it is a common research practice among labour economists to study self-employment, but call it entrepreneurship. Studies of entrepreneurial earnings are, therefore, based almost entirely on the experiences of self-employed individuals. Conflating entrepreneurship and self-employment is expedient for research purposes, but requires a degree of caution in the interpretation of research results.

The calculation of earnings also requires explanation. Occupational earnings usually involve a simple calculation of hourly wage, where the numerator is actual earnings and the denominator is usual hours (Skinner, Stuttard, Beissel-Durrant and Jenkins, 
2002). The standard measure of self-employed 'wage' is net profit (Devine, 1995; Parker, Belghitar and Barmby, 2005), though measures such as drawings from the business or drawings plus growth in business equity have also been used (Hamilton, 2000; Allinson, Braidford and Stone, 2008). The reliability of self-employed earnings estimates raises obvious concerns regarding the understatement of business income (Kesselman, 1989; Williams, 2005; Cagetti and De Nardi, 2006). Net profit is usually minimized by entrepreneurs, primarily - but not solely - because this represents the taxable component of earnings. Similarly, drawings are often minimized by frugal entrepreneurs who may extract a small notional amount, but whose lifestyles often exceed the consumption otherwise afforded by the value of their drawings. The use of an 'equity adjusted draw' measure is more robust in so far as it attempts to include an increase in business value over time, but this measure is prone to such vast variations in individual experience as to render it virtually useless as a general indicator in large scale surveys.

Questions may also be asked about the veracity of self-reported working time estimates. The self-employed claim to work very long hours, a feature sometimes explained in terms of self-insurance against wage uncertainty (Parker, Belghitar and Barmby, 2005; Hyytinen and Ruuskanen, 2007). Unlike employees, whose working hours reported by employers are often much lower than the actual hours worked, the self-employed are able to self-report their working time estimates. The long working hours commonly reported by the self-employed may be an accurate reflection of work patterns, but equally these may be exaggerated, perhaps in an effort to convey the perceived pressures and importance of their role. While self-employed incomes are prone to under-statement, their claimed working hours may be prone to over- 
statement, at least in relation to employees. The potential effect of these research practices on the calculation of hourly wage for the self-employed is to minimize the numerator (actual earnings) and exaggerate the denominator (usual hours), producing artificially low earnings estimates.

Given the method of calculation, it is not surprising that many studies report lower median earnings in self-employment than wages and salary earnings derived from employment (Parker, 1997; Hamilton, 2000; Blanchflower, 2004; Parker, Belghitar and Barmby, 2005; Blanchflower and Shadforth, 2007).

In one of the most widely cited studies, Hamilton (2000) found the self-employed to have both lower initial earnings and lower earnings growth, amounting to $35 \%$ median earnings differential over ten years. Controlling personal characteristics and wage distributions prior to entering self-employment, the results were stable across all industry sectors and across three separate measures of self-employed income: net profit (as reported to tax authorities); the draw (money withdrawn in salary by business owners); and the 'equity-adjusted draw' (the sum of the draw in period $t$ and the change in business equity between the start of the period $t$ and period $t+1$ ). Further, median earnings among the self-employed were found to be "always less than the predicted starting wage (for zero job tenure) available from an employer, regardless of the length of time in business" (Hamilton, 2000: 606).

More complex patterns of earnings have also been reported, largely reflecting the heterogeneity of the work undertaken by the self-employed (Meager and Bates, 2001), and individual characteristics (Burke, FitzRoy and Nolan, 2000; Hundley, 2000). In 
comparison with employees, the self-employed have a greater variability in earnings, being over-represented at both the highest and lowest ends of overall income distribution, and earnings inequality among the self-employed has increased over time (Parker, 1997). A handful of high earning 'superstars' (Rosen, 1981; Krugman, 2007) occupy the upper earnings quartile, while the lowest earning $10 \%$ of the selfemployed population report zero and even negative earnings (Blanchflower, 2004; HMRC, 2007).

\section{The Myth of the Compensating Differential?}

Explanations of low earnings in self-employment emphasize the role and importance of non-pecuniary benefits, such as independence, flexibility and job satisfaction, as compensation for low financial rewards (Blanchflower and Oswald, 1992; Hamilton, 2000; Blanchflower, 2004; Shane, 2008). Hamilton (2000:629) provides a typical example, “The self-employed earnings differential reflects entrepreneurs' willingness to sacrifice substantial earnings in exchange for the non-pecuniary benefits of owning a business". Surprisingly few studies of entrepreneurial earnings have collected data concerning the existence and precise nature of the compensating differential. Most assume its presence circumstantially, citing studies that report higher levels of autonomy and satisfaction among entrepreneurs as explanation for the entrepreneurial earnings anomaly.

The existence of a compensating differential is persuasive given the apparent financial irrationality of the individual's decision to pursue entrepreneurship as a career option, coupled with studies that have stressed the personal benefits associated with being 
one's own boss. But, given the importance of relative incomes (Blanchflower and Oswald, 2004) and the considerable difference between self-employed and employed earnings, further consideration is required of the precise nature and role of compensating differentials.

Studies that have considered the non-pecuniary dimensions of work highlight four core job characteristics that contribute towards job satisfaction: autonomy, task identity, task variety and performance feedback (Schjoedt, 2009a, 2009b). The search for enhanced levels of job satisfaction and hence an improved quality of life, often articulated as work-life balance, has preoccupied organizational and HR theorists in studies of the organizationally employed (Eikhof, Warhurst and Haunschild, 2007; Roberts, 2007; Warhurst, Eikhof and Haunschild, 2008), but such studies have rarely considered entrepreneurs as a distinct group requiring separate consideration. One explanation for the exclusion of entrepreneurs from such studies may be that entrepreneurship, unlike organizational employment, provides individuals with the means of controlling the critical dimensions of job satisfaction. Certainly, one of the few studies comparing job satisfaction levels of entrepreneurs and non-founding managers found autonomy, task variety and performance feedback to be significant predictors of job satisfaction among entrepreneurs (Schjoedt, 2009a).

For the purposes of this paper, the importance of job satisfaction components lies in the extent to which these non-pecuniary rewards of entrepreneurship compensate for relatively low earnings. The popular view, for which there is ample scientific evidence, suggests that a key motivating factor in the decision to pursue an entrepreneurial career is a desire for independence and control over one's working life 
(Kolvereid, 1996; Bradley and Roberts, 2004). Entrepreneurs not only benefit from enhanced levels of autonomy, but also other dimensions of job satisfaction. Task identity, defined as the completion of whole piece of work or doing a job from beginning to end (Hackman and Oldham, 1976; Schjoedt, 2009b); task variety, the extent to which a job involves different activities; and feedback, the availability of clear and direct performance measures, such as sales, positive cash flow etc (Schjoedt, 2009b), are not only evident, but are amplified, within entrepreneurship.

However, entrepreneurs are often viewed as wealth maximizers as well as being wealth creators. Prima facie it appears inconceivable that so many would be prepared to accept the non-pecuniary rewards of entrepreneurship in compensation for low personal financial rewards. An alternative explanation of the popular appeal of entrepreneurship, despite apparently low earnings, may lie in the view that a much larger proportion of entrepreneurs are able to achieve a relatively high standard of living than is indicated by the current conventional measures of earnings. Indeed, the perception that the living standards of the self-employed are substantially higher than their reported low incomes suggest, has led to several studies attempting to quantify the scale of under-reporting. Various estimates suggest that the under-reporting of entrepreneurial earnings amounts to the equivalent of between $28 \%-40 \%$ the value of reported earnings (Kesselman, 1989; Williams, 2005; Cagetti and De Nardi, 2006).

Further evidence of the under-reporting of entrepreneurial earnings can be seen in studies that have assessed comparative living standards and relative consumption as indicated by household expenditure (Bradbury, 1996). The relationship between household expenditure and consumption is much weaker for the self-employed than 
the employed. Unlike employee households, self-employed households have access to a range of business-related goods and services, particularly cars, computers, cleaning services etc., at relatively low or zero charge. Household consumption of business expenses simultaneously reduces household expenditure and increases living standards. The personal consumption of business-related goods contributes a substantial subsidy to the entrepreneurial household, increasing their overall 'consumption capability' by 34\% above reported income levels (Bradbury, 1996), ensuring higher average living standards for entrepreneurial households than employee households on the equivalent reported income.

The apparent financial irrationality of entrepreneurship, where individuals may anticipate earning 35\% less income than in equivalent employment (Hamilton, 2000), appears more rational in the light of other evidence indicating earning under-estimates of between $28 \%-40 \%$, and a consumption capability $34 \%$ higher than employees on equivalent earnings. This evidence suggests the view that low incomes in entrepreneurship are compensated by non-pecuniary rewards (the poor-but-happy thesis) is, at best, over-simplistic. While various reports highlight the range of advantages widely experienced by entrepreneurs, such as autonomy and other components of job satisfaction, these, perhaps, should not be seen as compensation for meagre financial returns, but additional benefits supplementing a range of financial returns that are in many cases no less, and often much more, than those experienced by employees. 


\section{Entrepreneurial Wealth}

In contrast to research on self-employed incomes, studies of household wealth typically find a "tight relationship between being an 'entrepreneur' and being rich" (Cagetti and De Nardi, 2006:838). The distribution of wealth is substantially more concentrated than the distribution of incomes (Krugman, 2007). Between 60\% and $70 \%$ of wealth is concentrated in the top $10 \%$ of US households and between $22 \%$ and $30 \%$ of wealth is owned by the top $1 \%$ of US households (Quadrini, 2000). The wealthiest households are more likely to comprise entrepreneurs than employees. Over $80 \%$ of the top $1 \%$ wealthiest households are classified as entrepreneurs (either self-employed and/or business owners). Business owners tend to be richer than the self-employed, and all entrepreneurs, irrespective of definition used, tend to be richer than non-entrepreneurs. The median net worth of business owners in the US is estimated to be $\$ 179,000$, compared with $\$ 169,000$ for the self-employed and $\$ 47,000$ for the population as a whole (Cagetti and De Nardi, 2006). Further evidence that entrepreneurship may lead to great wealth can be gleaned from an analysis of the Forbes list of the wealthiest 400 Americans. Over various recent years, between 61\% and $80 \%$ of Forbes list members were business owners, while most of the rest inherited their wealth, typically made from businesses started by their parents or grandparents (Cagetti and De Nardi, 2006).

The concentration of wealth owned by entrepreneurs cannot be explained by their incomes, which are disproportionately lower than their wealth (Quadrini, 2007). Instead, two alternative explanations of entrepreneurial wealth have been proposed. Firstly, there is evidence that the greater wealth of entrepreneurs is a result of different patterns of accumulation and higher levels of savings (Quadrini, 2000; 
Bradford, 2003; Cagetti and De Nardi, 2006). Lump sum payments, for example, annual shareholder dividends, are more likely to occur within entrepreneurial households than within employee households. Thus, entrepreneurs may have access to potentially large lump sums on a reasonably regular basis. Entrepreneurial households also have a greater incentive than employee households to save considerable sums, both because of their need to offset large earnings risks and also to reduce the requirement for costly external finance (Gentry and Hubbard, 2004; Parker et al, 2005). Unlike employees with regular salary payments and some confidence of job continuity, entrepreneurs face a considerable risk that future lump sums may not accrue due to the high potential for downturns in business fortunes. Hence, the incentive to save is much stronger in entrepreneurial households than in employee households. In practice, therefore, entrepreneurs have both the means and the motive to accumulate wealth and, given the opportunity, will do so.

Secondly, there is also evidence that the wealth of entrepreneurial households is not so much an outcome of entrepreneurship as it is an input. In other words, the wealthy do not achieve their wealth as a consequence of entrepreneurship; they become entrepreneurs as a consequence of being wealthy. Research has shown that the wealthy are more likely than the non-wealthy to be entrepreneurs (Quadrini, 2000; Nanda, 2008). Entrepreneurship offers an appealing occupational choice for wealthy individuals, providing all the benefits of a fulfilling and creative occupation while allowing the retention of autonomy within the workplace. But the greater selection of entrepreneurship among wealthier households is probably best explained by the absence of borrowing constraints (Gentry and Hubbard, 2004; Nanda, 2008). In contrast, the opposite has been seen among non-wealthy households, where credit 
rationing may constrain venture start-up and growth among those with a reliance on external finance (Stiglitz and Weiss, 1981; Levenson and Willard, 2000; Freel, 2007). Not only does household wealth reduce or remove the need for external finance, where external finance is required personal wealth is becoming increasingly important as a means of collateralizing business liabilities (Avery, Bostic and Samolyk, 1998).

\section{Measuring Entrepreneurial Rewards: The Components of Economic Wellbeing}

The conflicting evidence emanating from studies of entrepreneurial incomes and wealth highlights the complexities involved in studying the financial rewards of entrepreneurship. The rewards of entrepreneurship are multi-faceted, and include different types and amounts of rewards at different stages of the business lifecycle. However, the narrow and static measures that are conventionally used, focusing either on incomes or on wealth, capture neither the multi-faceted nature of entrepreneurial rewards nor the variations in these rewards that may occur over time. While there are obvious advantages to the use of incomes as a measure of financial reward, being a readily available measure that allows comparisons with other occupational groups, few entrepreneurship scholars would be comfortable with the simplistic and often misleading statements that have emerged from such studies. In contrast, studies of entrepreneurial wealth suggest that the rewards of entrepreneurship may be large, at least for some, but these studies focus only on a small number of very successful cases, while ignoring the experiences of the vast majority of entrepreneurs. Neither incomes nor wealth, as individual measures, fully capture the range of financial rewards available to the entrepreneur and the ways in which economic wellbeing is constructed over the life course of the venture. 
This inevitably begs the question of how the financial rewards of entrepreneurship should be measured. There appear to be five main aspects of entrepreneurial reward structures that require consideration (Hill, 1982). Firstly, there is the definitional aspect, that is, the items that should be included in the assessment of financial rewards. Extant research suggests that net profit, drawings and capital gains need be included, but other business and individual factors may also require assessment. Secondly, there is a distributional aspect that includes the potentially large variations in entrepreneurial earnings. It is reasonable to assume that entrepreneurial earnings are unevenly distributed between firms, depending on their relative individual success; between high and low value industry sectors; between regions depending on levels of economic prosperity; and over time given the substantial likely variation in financial returns over the life cycle of the business and the individual. Thirdly, there is the economic status aspect. As entrepreneurial incomes rarely reflect the living standards and lifestyle of the household, some consideration need be given to other factors, such as wealth, assets and savings that also contribute to the entrepreneur's living standard, and the extent to which these have accrued as a direct result of business ownership or are derived from independent sources. Fourthly, the businesshousehold aspect highlights the permeability of the boundaries between the business and the household with regard to earnings, wealth, expenditure and consumption, and requires consideration because of the possibility of cross-subsidy between the business and the household spheres. Finally, there is the multiple income aspect. An entrepreneur may have multiple sources of incomes, which may accrue from the ownership of multiple businesses, additional full-time or part-time employment outside of the enterprise, shareholdings and equity stakes in other businesses, or from 
social security transfers and incomes generated by other household members, all of which contribute to an overall household living standard.

Considering these differing aspects of entrepreneurial rewards implies a move away from single measures, such as incomes or wealth, to the use of new multi-dimensional measures of economic wellbeing that provide a broader perspective on the variety of reward mechanisms available to the entrepreneur. Economic wellbeing comprises composite measures of financial rewards including earnings, wealth, assets, savings and pensions, as well as highly subjective and individualized measures of consumption, lifestyle and living standards. Unlike static measures such as incomes or wealth, multi-dimensional measures of economic well-being have the capacity to capture relative prosperity over different time-periods, and therefore offer a more comprehensive and dynamic view of entrepreneurial rewards. Importantly, where prior studies have presented atomized views of the individual entrepreneur acting in isolation and making decisions for individual benefit, multi-dimensional measures of economic wellbeing contextualize the entrepreneur within the household. Entrepreneurs have considerable scope in determining the type, value and timing of their financial rewards, which may be adjusted to suit different household, as well as business, requirements (Wheelock and Baines, 1998; Ram, 2001; Aldrich and Cliff, 2003). Thus, a focus on economic wellbeing emphasizes the role of the household as a key influence on entrepreneurial reward decision making. 


\section{Contextualizing Economic Wellbeing: The Role of the Household}

Although business and household have been traditionally regarded as separate spheres, there has been a growing realization that the two institutions are inextricably linked (Mulholland, 1996; Wheelock and Mariussen, 1997; Wheelock and Baines, 1998; Ram, 2001; de Man, de Bruijn and Groeneveld, 2008), coupled with persuasive calls to embed entrepreneurship research within the context of the family (Aldrich and Cliff, 2003). Research that focuses on the financial rewards of entrepreneurship immediately highlights the centrality of the entrepreneurial household as a key influence on reward decision-making. The influence of the family and household can be seen in a number of ways, including in the management of uncertain and irregular rewards; in distinctive patterns of consumption and savings; and, by providing a subsidy for entrepreneurship through waged employment. These examples are considered below.

In comparison with wage and salary rewards derived from employment, the financial rewards of entrepreneurship are characterized as uncertain and irregular. These financial rewards do not only impact on the individual, but have wider repercussions on the family who also sacrifice certainty and regularity in household income. How these uncertain and irregular rewards are managed, and their potential effects within the entrepreneurial household has yet to be explained. In general, there is little detailed understanding of the relationship between income and expenditure at the household level. While there have been some attempts to open the 'black box' that occupies the space between household earnings and household spending, this has mainly focused on exploring control of money in marriage and patterns of expenditure within waged employee households (Pahl, 1990; 1994). It is doubtful whether the 
experiences of waged employees can be applied to entrepreneurial households to any meaningful extent. Mulholland's (1996) analysis of gender, power and property relations within extremely wealthy, multi-generational entrepreneurial families challenged the popular view of men as the central agents of wealth creation and women as beneficiaries and consumers, but similarly her findings may not apply to the quotidian experience of less illustrious (and first generation) entrepreneurs. While these studies offer the tantalising promise of what future research might reveal about the influence of uncertain and irregular rewards on both business and family decisions and business-family interaction, for now these elements of entrepreneurial households remain firmly locked inside a black box.

It is, however, clear that one consequence of reward uncertainty is the necessity to engage in markedly different patterns of expenditure and savings at the household level. Within entrepreneurial households, consumption in the form of direct expenditure is adjustable to suit prevailing economic conditions. However, even in periods of relative economic prosperity, personal consumption is tempered by the need for substantial savings in order to offset large future earnings risks. In comparison with employee households, entrepreneurial households are likely to be more typified by minimized levels of expenditure and higher levels of savings (Quadrini, 2000; Cagetti and De Nardi, 2006). The reasons why some households are prepared to accept the uncertain and irregular rewards, frugal consumption and strong savings impetus that accompanies entrepreneurship, where other households prefer the certainties of employment are largely unknown. It is likely that individual entrepreneurial households perceive and attend to the management and negotiation of 
entrepreneurial rewards differently, but the precise dimensions that underpin these variations between households are similarly unknown.

While conventionally it may be assumed that financial rewards earned outside of the household subsidize the domestic and family sphere, in entrepreneurial households the business-household relationship is likely to be more complex. In a simple scenario, the financial rewards of entrepreneurship, including visible earnings as well as additional 'invisible' inputs such as goods and services, are allocated and consumed by the household. However, the 'inextricably intertwined' relationship between business and household (Aldrich and Cliff, 2003: 573) suggests the possibility of other scenarios, two examples of which are discussed below.

Firstly, studies of self-employed households demonstrate that an individual is more likely to become self-employed if their spouse is in paid employment (Devine, 1994a; Wellington, 2006). Within conventional, two partner households, the regular wage or salary income and the fringe benefits of employment, for example health insurance, earned by one partner, provide financial security to the household, allowing the other partner to pursue their entrepreneurial ambitions. Hence, waged employment undertaken by a household member acts as a subsidy to entrepreneurship by removing the burden of household income generation. To date, evidence of household subsidies to entrepreneurship has mainly focused on self-employed women 'subsidized' by employed spouses (Devine, 1994a; 1994b). However, it is likely that the alternative, male entrepreneurship 'subsidized' by female waged employment, may be equally apparent. Indeed, given the relatively higher rates of male self-employment, a female waged employment subsidy to male entrepreneurship may be more common. 
Secondly, there is evidence that within many entrepreneurial households, incomes are derived from multiple sources, including the ownership of multiple businesses, the purchase of commercial and domestic property for onward rental, employment of household members, shareholding and equity portfolios, pensions, grants and social security transfers (Carter, Tagg and Dimitratos, 2004). The diversification of household income over a broad range of economic activities reduces household dependency on the enterprise, enabling the household to 'patchwork' incomes from a number of sources (Kibria, 1994; Mulholland, 1997; Carter et al, 2004). At the same time, multiple income sources within the household offer advantages to the business, both by relieving the pressure to generate household income (Mulholland, 1996) and by providing a source of readily available external finance when required (Gentry and Hubbard, 2004).

While these examples suggest a great potential for cross-subsidy between the business and the household, highlighting financial interactions in which each institution supports the other, the extent to which this occurs and the impact of the interaction on business and household, has so far eluded research scrutiny. Not only is there scant appreciation of the precise dimensions of the inter-twined relationship between business and household, there is also very little understanding of the household reasoning that underpins entrepreneurial reward decisions. Entrepreneurial households are distinctive from employee households in so far as they are able to make decisions about the type, value and timing of financial rewards, and negotiate expenditure and savings patterns at the household and business level. But, the ways in which these resources are controlled, and by whom, remains unknown. 
It is also possible to speculate that entrepreneurial households are likely to vary in their approaches to financial rewards over the lifecycle of the business and dependent on the venture's relative success. In households where new ventures have been recently started, uncertain and irregular financial rewards may be viewed as a temporary situation, accepted on the basis that future gains will accrue. This approach to deferring entrepreneurial rewards at the outset of the venture suggests a transitional entry thesis, where it is expected that venture growth will bring increasing rewards for the household over time (Carter et al, 2004). However, in households where ventures are more established, financial rewards will vary according to the degree of venture success. Some ventures may return levels of earnings and living standards well above average. In these cases, reward decision making is facilitated by the presence of a greater volume and value of entrepreneurial resources that become available to the household. In other ventures, low initial rewards may persist with little prospect of future growth. In these cases, the household's approach to reward decision making may evolve from a transitional entry approach to a traditional economy approach (Mariussen, Wheelock and Baines, 1997; Baines and Wheelock, 1998; Carter et al, 2004). In the traditional (peasant) economy model, the household relies on a patchwork of alternative income sources to supplement low entrepreneurial rewards and variations in personal and household consumption appropriate to the prevailing conditions (Friedmann, 1986; Kibria, 1994; Mulholland, 1997). 


\section{Researching Entrepreneurial Rewards}

The discussion so far has highlighted a variety of weaknesses that have arisen in previous empirical studies of entrepreneurial incomes and wealth, and also some of the issues that might fruitfully be addressed by future research exploring entrepreneurial rewards. To a large degree, the problems that have been seen within extant empirical studies have been caused by the over-reliance of entrepreneurship scholars on the work of labour economists who, appropriately for their purposes, have depended upon measures that allow comparisons between occupational groups, but which fail to account for the broad spectrum of rewards routinely available to entrepreneurs. Arguably, the specialist insights acquired by entrepreneurship scholars are crucial in developing a full understanding of entrepreneurial rewards. Nevertheless, the entrepreneurship research domain has yet to engage in any meaningful way with issues relating to entrepreneurial rewards.

For entrepreneurship researchers, a focus on entrepreneurial rewards brings two main challenges. The first challenge is the need to consider the "conceptual landscape" of entrepreneurial rewards, identifying the four building blocks (the 'what', 'how', 'why' and 'who, where and when' elements) required for theory development (Whetton, 1989:490). The first building block (the 'what' question) requires a shift in the dependent variable away from narrow and static measures of incomes and wealth to consider the, arguably more interesting, question of what factors constitute and contribute towards economic well-being within entrepreneurship. The second building

block (the 'how' question) requires a consideration of entrepreneurial reward structures and processes at the level of the firm and the household. The third building block (the 'why' question) highlights the contextual conditions and circumstances 
relevant to entrepreneurial reward structures and processes and which contribute to their full meaning, and thus firmly locates entrepreneurial reward decisions within the context of the entrepreneurial household. The fourth building block (the 'who, where and when' elements) equally demand consideration of the household as well as the business context, as both institutions play a central role in entrepreneurial reward decisions.

The second challenge is the need to consider the methodological implications associated with studying entrepreneurial rewards. This requires the development of new multi-dimensional measures of entrepreneurial rewards that capture the range of earnings available to an entrepreneur and which collectively contribute to their economic wellbeing. Such measures should reflect how entrepreneurial lifestyles are constructed and contextualise these within the entrepreneurial household. While the development of new multi-dimensional measures of entrepreneurial earnings and economic wellbeing are important, this is not the only methodological consideration. Equally important is the need to move away from static and cross-sectional analyses that measure rewards at a particular point in time, towards more dynamic and longitudinal analyses that can track the variations in entrepreneurial rewards over the business lifecycle.

While these are large and difficult research challenges, there are considerable benefits to be gained from engaging with these complex issues. The knowledge gained from a new research effort directed towards entrepreneurial rewards promises to extend current knowledge of the entrepreneurship research domain in several important ways. Knowledge of entrepreneurial rewards offers the ability to inform theoretical 
debates regarding, for example, the derivation of entrepreneurial rents by shedding new light on the precise sources of value created by different enterprises. This research focus also has the potential to inform empirical debates, for example contributing new insights into venture performance that look beyond firm-level measures such as sales turnover, to consider the rewards of entrepreneurship at the level of the individual and the household. Researching entrepreneurial rewards also has policy relevance, for example a broader knowledge of the types of rewards and lifestyles that can be achieved through entrepreneurship may help to mitigate much of the uncertainty assumed by the individual considering new venture start-up. These efforts will bring new insights into the financial consequences and rewards of entrepreneurial action that can address future research questions, such as:

1. What are the components of economic well-being in entrepreneurship? To what extent do the relative financial components of wellbeing vary over time, and between entrepreneurial ventures? What dimensions underpin any potential variance?

2. What is the relationship between entrepreneurial rewards and venture performance? How does venture performance translate into rewards at the individual and household level?

3. To what extent does overall economic wellbeing achieved through entrepreneurship over the lifecycle of the venture compare with the financial returns from alternative occupations?

4. What is the nature of the 'intertwined' relationship between entrepreneurial household and entrepreneurial venture with regard to the construction of economic wellbeing? 
5. How are uncertain rewards managed, and consumption and savings patterns negotiated between the household and the venture? How do the negotiated outcomes vary across the business and household lifecycle?

6. What is the relative role of the household and the venture in reward decision making processes and controls?

\section{Concluding Comments}

Entrepreneurship scholars have shown remarkably little interest in the financial consequences and rewards of entrepreneurial action for the individual. One explanation for this lies in the obvious research difficulties in pursuing this theme: measures of financial rewards are not immediately obvious, data collection requires the probing of sensitive information; and the unit of analysis is ambiguous. Nevertheless, the engagement of labour economists in this issue, without the tempering views of entrepreneurship scholars, has resulted in a distorted picture of entrepreneurial impoverishment. Indeed, one economist, noting the relatively few individuals pursuing entrepreneurship despite its popular appeal, argued that "people may well be able to judge what is in their own best interests - that is why they remain as employees” (Blanchflower, 2004:1). Certainly, 'wage uncertainty' remains a key deterrent on individuals interested in pursuing new ventures (Parker, 1997). The lack of engagement of entrepreneurship scholars in issues relating to the financial rewards of entrepreneurship has also allowed obvious methodological flaws to persist unchallenged. In particular, the continued use of income variables based on net profit and drawings, raises immediate concerns about the reliability and veracity of accepted prior knowledge. 
A more accurate picture of the financial rewards of entrepreneurship can only be gained by moving beyond narrow and static measures of performance, to consider the broad range of financial rewards that collectively contribute to overall economic wellbeing over time. The financial rewards of entrepreneurship are multi-faceted, and include different types and amounts of rewards at different stages of the business lifecycle. How the components of rewards collectively contribute to economic wellbeing, and how variance may occur over the course of the business lifecycle has yet to be determined. Moreover, there is a need to contextualize economic wellbeing within the entrepreneurial household, as reward decision making is not only determined by business rationality, but is influenced by family and household needs. The analysis of entrepreneurial rewards requires an approach that captures the processes and dynamics of reward decision-making over the business lifecycle, while contextualising decisions pertaining to venture creation and growth, and the scale and timing of rewards, within the entrepreneurial household 


\section{References}

Aldrich, H.E. and Cliff, J.E. (2003). The Pervasive Effects of Family on Entrepreneurship: Toward a Family Embeddedness Perspective. Journal of Business Venturing, 18(5), 573-596.

Astebro, T. and Thompson, P. (2007) Entrepreneurs: Jacks of all Trades or Hobos? Florida International University Department of Economics, Working Paper 0705.

Avery, R.B., Bostic, R.W. and Samolyk, K. (1998). The Role of Personal Wealth in Small Business Finance. Journal of Banking and Finance, 22, 6-8, pp1019-1061.

Baines, S. and Wheelock, J. (1998). Reinventing Traditional Solutions: Job Creation, Gender and the Micro-Business Household. Work, Employment and Society, 12: 579601.

Blanchflower, D.G. (2004). Self-employment: More May Not be Better. NBER Working Paper No. W10286, Cambridge, MA: National Bureau of Economic Research.

Blanchflower, D.G. and Oswald, A.J. (2004). Well-being Over Time in Britain and the USA. Journal of Public Economics, 88 (7-8), 1359-1386.

Blanchflower, D.G. and Shadforth, C. (2007). Entrepreneurship in the UK. Foundations and Trends in Entrepreneurship, 3 (4), 257-64. 
Bradbury, B. (1996). Are the Low Income Self-employed Poor? Social Policy Research Centre Discussion Paper 73. Sydney: University of New South Wales.

Bradford, W.D. (2003). The Wealth Dynamics of Entrepreneurship for Black and White Families in the US. The Review of Income and Wealth 49 (1), 89-116.

Bradley, D.E and Roberts, J.A. (2004). Self-employment and Job Satisfaction: Investigating the Role of Self-efficacy, Depression and Seniority. Journal of Small Business Management, 42: 37-58.

Burke, A.E. FitzRoy, F.R. and Nolan, M.A. (2000). When Less is More: Distinguishing Between Entrepreneurial Choice and Performance. Oxford Bulletin of Economics and Statistics 62(5), 565-587.

Cagetti, M. and De Nardi, M. (2006). Entrepreneurship, Frictions and Wealth. Journal of Political Economy 114 (5), 835-870.

Cantillon, R. (1964). Essai sur la Nature du Commerce en General. (1755) (Trans : Higgs) New York : A.M. Kelly Publishers.

Carruth, A. Collier, W. and Dickerson, A. (2004). Inter-industry Wage Differences and Individual Heterogeneity. Oxford Bulletin of Economics and Statistics 66(5): 811846. 
Carter, S. Tagg, S. and Dimitratos, P. (2004). Beyond Portfolio Entrepreneurship:

Multiple Income Sources in Small Firms. Entrepreneurship and Regional Development, 16, 481-499.

Casson, M. (1995). Entrepreneurship and Business Culture: Studies in the Economics of Trust. Aldershot: Edward Elgar.

Casson, M. (2005). Entrepreneurship and the Theory of the Firm. Journal of Economic Behavior and Organization. 58: 327-48.

Chandler, G.N. and Lyon, D.W. (2001). Issues in Research Design and Construct Measurement in Entrepreneurship Research: The Past Decade. Entrepreneurship Theory and Practice, 25 (4), 101- 113.

Davidsson, P. and Wiklund, J, (2001). Levels of Analysis in Entrepreneurship Research: Current Research Practice and Suggestions for the Future. Entrepreneurship Theory and Practice, 25 (4), 81-100.

De Man, R. de Bruijn, J. and Groeneveld, S. (2008). What Makes the Home Boundary Porous? The Influence of Work Characteristics on the Permeability of the Home Domain. In C. Warhurst, D.R. Eikhof and A. Haunschild (eds) Work Less, Live More? Critical Analyses of the Work-Life Boundary. London: Palgrave. 
Devine, T. (1994a). Changes in Wage-and-Salary Returns to skill and the Recent Rise in Female Self-employment. American Economic Review, 84 (2), 108-113.

Devine, T. (1994b). Characteristics of Self-employed Women in the United States. Monthly Labor Review, 117 (March), 20-34.

Eikhof, D.R., Warhurst, C. and Haunschild, A. (2007). What Work? What Life? What Balance? Critical Reflections on the Work-Life Balance Debate. Employee Relations 29(4): $325-333$

Evans, D.S. and Leighton, L.S. (1989). Some Empirical Aspects of Entrepreneurship. The American Economic Review, 79 (3), 519-535.

Foss, N.J. and Klein, P.G. (2004). Entrepreneurship and the Economic Theory of the Firm: Any Gains to Trade? University of Missouri-Columbia, Working Paper 2004/9.

Freel, M. (2007) Are Small Innovators Credit Rationed? Small Business Economics, $28,23-35$

Friedmann, H. (1986). Family Enterprise in Agriculture: Structural Limits and Political possibilities. In G. Cox, P. Lowe and M.Winter (eds). Agriculture: People and Policies, London: Allen and Unwin, pp.41-60.

Gentry, W.M. and Hubbard, R.G. (2004). Entrepreneurship and Household Saving. Advances in Economic Analysis and Policy, 4(1) 
Hackman, J.R. and Oldham, G. R. (1976). Motivation Through the Design of Work: Test of a Theory. Organizational Behaviour and Human Performance, 16(2): 250279.

Hamilton, B. H. (2000). Does Entrepreneurship Pay? An Empirical Analysis of the Returns to Self-employment. Journal of Political Economy, 108 (3), pp. 604-631.

Hill, B. (1982). Concepts and Measurement of the Incomes, Wealth and Economic Well-being of Farmers. Journal of Agricultural Economics. 33 (3): 311-324.

HMRC (2007). Survey of Personal Incomes (2005-2006). http://www.hmrc.gov.uk/stats/income_distribution/table3-9-oct07.pdf

Hundley, G. (2000). Male/Female Earnings Differences in Self-employment: The Effect of Marriage, Children and the Household Division of Labor. Industrial and Labor Relations Review 54 (1), 95-114.

Hyytinen, A. and Ruuskanen, O. (2007). Time Use of the Self-employed. Kyklos, 60(1), 105-122.

Jovanovic, B. (1982). Selection and Evolution of Industry. Econometrica, 50, 649670. 
Kesselman, J.R. (1989). Income Tax Evasion: An Inter-sectoral Analysis. Journal of Public Economics, 38, 137-182.

Kibria, N. (1994). Household Structure and Family Ideologies: The Dynamics of Immigrant Economic Adaptation Among Vietnamese Refugees. Social Problems, 41 (1), 81-96.

Kirzner, I. (1979). Perception, Opportunity and Profit: Studies in the Theory of Entrepreneurship. Chicago: University of Chicago Press.

Kolvereid, L. (1996). Organizational Employment versus Self-employment: Reasons for Career Choice Intentions. Entrepreneurship Theory and Practice, 20: 23-31.

Krugman, P. (2007). The Conscience of a Liberal. New York: W.W. Norton \& Co.

Lazear, E. (2005). Entrepreneurship. Journal of Labor Economics, 23(4), 649-680.

Levenson, A. R. and K. L. Willard, 2000. Do Firms Get the Financing They Want? Measuring Credit Rationing Experienced by Small Business in the U.S. Small Business Economics, 14, 83-94

Mariussen, A. Wheelock, J. and Baines, S. (1997). The Family Business Tradition in Britain and Norway: Modernization and Reinvention? International Studies of Management and Organization, 27(3):64-88. 
Meager, N. and Bates, P. (2001). The Self-employed and Lifetime Incomes: Some UK Evidence. International Journal of Sociology, 31(1), 27-58.

Mulholland, K. (1996). Gender Power and Property Relations within Entrepreneurial Wealthy Families. Gender, Work and Organization 3(2), 78-102.

Mulholland, K. (1997). The Family Enterprise and Business Strategies. Work, Employment and Society, 11, 685-711.

Nanda, R. (2008). Cost of External Finance and Selection into Entrepreneurship. HBS Entrepreneurial Management Working Paper 08/047, Cambridge, MA: Harvard Business School.

Pahl, J. (1990) Household Spending, Personal Spending and the Control of Money in Marriage. Sociology 24(1), 119-138.

Pahl, J. (1994). His Money, Her Money: Recent Research on Financial Organisation in Marriage. Journal of Economic Psychology 16(3), 361-376.

Parker, S. (1997). The Distribution of Self-employment Income in the United Kingdom, 1976-1991. The Economic Journal 107, March, 455-466.

Parker, S. Belghitar, Y. and Barmby, T. (2005). Wage Uncertainty and the Labour Supply of Self-employed Workers. The Economic Journal. 115 (March), C190-C207. 
Polkovnichenko, V. (2002). Human Capital and the Private Equity Premium. Review of Economic Dynamics, 6(4), 831-845.

Quadrini, V. (2000). Entrepreneurship, Saving, and Mobility. Review of Economic Dynamics, 3, 1-40.

Ram, M. (2001). Family Dynamics in a Small Consultancy Firm. Human Relations, $54(4), 395-418$.

Roberts, K. (2007). Work-Life Balance - the Sources of the Contemporary Problem and the Probable Outcomes. Employee Relations, 29(4): 334-351.

Rosen, S. (1981), The Economics of Superstars. American Economic Review, 71 (5), 845-858.

Ross, R.B. and Westgren, R.E. (2006). Economic Returns to Entrepreneurial Behavior. Journal of Agricultural and Applied Economics. 38 (2), 403-419.

Schjoedt, L. (2009a). Entrepreneurial Job Characteristics: An Examination of their Effects on Entrepreneurial Satisfaction. Entrepreneurship Theory and Practice, 33(3): 619-644.

Schjoedt, L. (2009b). Job Characteristics Theory: A Comparative Study of Novice and Repeat Entrepreneurs. Babson Kauffman Entrepreneurship Research Conference, Babson College, MA. 
Schumpeter, J.A. (1934). The Theory of Economic Development: An Inquiry into Profits, Capital, Credit, Interest and the Business Cycle. Cambridge, MA: Harvard University Press.

Schumpeter, J.A. (1991). The Economics of Sociology of Capitalism. Ed R.Swedberg, Princeton: Princeton University Press.

Shane, S. (2008). The Illusions of Entrepreneurship: The Costly Myths that Entrepreneurs, Investors and Policymakers Live By. New Haven: Yale University Press.

Skinner, C. Stuttard, N. Beissel-Durrant, G. and Jenkins, J. (2003). The Measurement of Low Pay in the UK Labour Force Survey. Oxford Bulletin of Economics and Statistics, 64 (Supplement 2002): 653-676.

Stiglitz, J. and Weiss, A. (1981) Credit Rationing in Markets with Imperfect Information, American Economic Review, 71, 393-410

Von Thunen, J. H. (1960) 'The Isolated State in Relation to Agriculture and Political Economy: Volume Two'. In B.W. Dempsey (ed) The Frontier Wage: The Economic Organization of Free Agents. Chicago: Loyola University Press.

Warhurst, C. Eikhof, D.R. and Haunschild, A. (2008). Out of Balance or Just Out of Bounds? Analysing the Relationship Between Work and Life. In C. Warhurst, D.R. 
Eikhof and A. Haunschild (eds) Work Less, Live More? Critical Analyses of the Work-Life Boundary. London: Palgrave.

Wellington, A.J. (2006). Self-employment: The New Solution for Balancing Family and Career. Labour Economics, 13(3), 357-386.

Wheelock, J. and Baines, S. (1998). Dependency of Self-reliance? The Contradictory Case of Work in UK Small Business Families. Journal of Family and Economic Issues 19 (1), 53-73.

Wheelock, J. and Mariussen, A. (Eds.) (1997). Households, Work and Economic Change: A Comparative Institutional Perspective. Boston: Kluwer.

Whetton, D.A. (1989). What Constitutes a Theoretical Contribution? Academy of Management Review 14(4), 490-495.

Williams, C.C. (2005). The Undeclared Sector, Self-employment and Public Policy. International Journal of Entrepreneurial Behaviour and Research, 11(4), 244-57.

Zahra, S. (2007). Contextualizing Theory Building in Entrepreneurship. Journal of Business Venturing. 22 (3), 443-452. 